\title{
ON THE TEN YARD COAL OF SOUTH STAFFORDSHIRE AND THE MODE OF WORKING.
}

By Mr. WILLIAM MATHEWS, OF CORBYN's HALl IroN Works, DUdLeY.

In the present paper it is not proposed to enter into any elaborate or scientific discussion of the South Staffordshire coalfield, but simply to describe that most important portion of it known as the Thick, Main, or Ten Yard Coal : a seam peculiar to this district, nothing similar having been found in this country or indeed in any other part of Europe, and on the occurrence of which the importance of the district, as well as its high character for the manufacture of iron, is chiefly founded. For this object it will be convenient to consider the subject under the following divisions :-

I. Geological character and extent of the South Staffordshire Coalfield, and of the Thick Coal particularly.

II. Mineralogical peculiarities of the Thick Coal.

III. Modes of Working the Thick Coal, and methods of Ventilation.

IV. Area of Thick Coal remaining unworked, and its probable duration at the present rate of working.

I. Geological character and extent of the South Staffordshire Coalfield, and of the Thick Coal particularly.

The South Staffordshire Coalfield has been very closely investigated and deseribed, not only by local men of intelligence and science, but more elaborately by Sir R. I. Murchison in his "Silurian System," and by Mr. Beete Jukes in his recent volume on the "South Staffordshire Coalfield" (1859), which exhausts all the knowledge at present attained on the subject. It will suffice therefore to confine this part of the paper to a reference to the accompanying general plan of the coalfield, Fig. 1, Plate 16, compiled from the geological ordnance survey, in which the extent of the coalfield is shown by the shaded portion. This plan comprises the whole 
mineral basin of South Staffordshire and East Worcestershire, which it will be seen is flanked by the great red sandstone faults of Great Barr and Cannock Chase on the east, and of Stourbridge, Kingswinford, and Wolverhampton on the west; which by their junction on the north and south limit the coalfield in those directions. The extreme length north and south is about 26 miles, and the width at the widest part about 6 miles, giving an area of 90 to 100 square miles. The whole coalfield rests unconformably on the upper silurian limestone, which comes up to the surface at several points, rising at the Wren's Nest Hill and Sedgley Beacon to an elevation of 730 feet and upwards above the sea level.

Upon this plan is further delineated by the black portion the region of the Thick Coal, occupying the whole of the southern area of the field. In the northern portion of the seam, namely that east of the Dudley limestone ridge, the working operations have been actively carried on for a long series of years; and it is on the southern portion that the district has now to depend for its chief supply of Thick coal. In this portion of the district only are the limits of the Thick coal still undefined, no proofs having been made further south than those at Cradley, Corngreaves, and Hawn near Halesowen, where the seam exists in perfect regularity, dipping slightly southwards. To what extent therefore the Thick coal may extend in this direction, what may be its quality or character, or what the difficulty of winning it, are problems yet to be solved. The extension of railways however into that locality, for which acts have been recently obtained, coupled with the pressing wants of the neighbouring ironworks and the rapid exhaustion of the Thick coal in other portions of the seam, must effect this solution at no very distant day. The disfigurement of the landscape follows as a natural result : already some of the fairest portions of that neighbourhood are invaded by the inexorable march of mineral operations, and the classic scenes of Hagley may ere long give place to the unsightly appliances and ungenial aspects of the dark genii of the coal mines. The northern limit of the Thick coal may be roughly defined by a line drawn from Monmore Green eastwards, a little north of Bilston, to Darlaston; whence the boundary trends in a southerly direction to Westbromwich, where the coal is terminated by 
the Great Barr sandstone fault before mentioned, which forms its eastern boundary: the Kingswinford sandstone fault forming the natural boundary on the west.

The general lie or position of the Thick coal will be more clearly comprehended by a reference to the sections of the coalfield, Figs. 2, 3, and 4, Plates 17 and 18. The first, Fig. 2, Flate 17, is a section from south to north, extending from the foot of the Clent Hills, through Dudley, Bentley, Norton, and Beaudesert, to Brereton near Rugeley, as shown by the dotted line from $\mathbf{S}$ to $\mathbf{N}$ on the plan, Fig. 1: the only portion to be referred to in connexion with the present subject is that terminating the Thick coal at Darlaston. The second section, Fig. 3, Plate 18, is taken from west to east, through Kingswinford, Dudley, and Westbromwich, as shown by the dotted line on the plan, commencing from the upper red sandstone measures, and crossing the coalfield through the limestone of the Dudley hills at right angles with the former section, and terminating with the permian or lower red sandstone at Westbromwich. The third section, Fig. 4, Plate 18, is also taken from west to east, parallel to the previous section, along the line $W$ to $E$ on the plan, passing through the basalt of Rowley.

Whilst however the Thick coal generally prevails over the area above indicated, it will be observed from the sections that it is by no means uniform and unbroken in its distribution. The boundary is somewhat modified by a termination of the bed by outcrop in some spots, short of the sandstone faults; and the general uniformity of the seam is materially dislocated and disturbed by the intrusion of the igneous rocks of the Rowley hills and at other spots, and incidentally of the subjacent measures, as well as by the occurrence of faults more or less extensive. The great anticlinal axis running nearly north and south from Wolverhampton east of Halesowen to the Lickey Hill cuts the Thick coal into two nearly equal divisions, one lying to the east of Dudley, the other to the west, forming two separate districts. These districts are subdivided by minor disturbances, forming other separate local basins, which are again intersected in various directions by faults and dislocations that have the effect of further subdividing the seam of coal into separate areas or patches of a comparatively limited extent, so 
as to interpose difficulties of a serious character to its effective working; difficulties which will have to be discussed more in detail presently, and which are only compensated by the great value of the seam itself.

\section{Mineralogical peculiarities of the Thick Coal.}

It is not within the province of this paper to suggest any theory as to the geological origin of the Thick coal : this has been done with great ability and originality of view by Mr. Jukes, in his recent work. With us its existence is a "great fact"; and until we have to grapple with it practically, this is all that concerns us. It may however be mentioned that Mr. Jukes considers the bed of Thick coal to have its origin physically in the close approximation of a number of seams of varying thicknesses, brought into contact by some fortuitous process ; and this view is supported by the fact of the bed being divided by distinet partings into the several divisions constituting its entire thickness. It is further strengthened by the well grounded supposition that the several portions of the Thick coal in the Bilston district can be identified with a separate series of thin coal seams in the Wyrley district, into which they have extended; and further by the fact that in other parts of the district the coal called the Flying Reed, consisting of the two top measures of the Thick coal, is gradually separated from the main bed by the intrusion of many yards of various rocks, as shown in Fig. 6, Plate 19, forming thenceforth an independent workable seam of thin coal. The several divisions of which the Thick coal is composed are too strongly defined to admit of much difference of opinion as to the soundness of this theory. Indeed these different divisions are clearly marked, the seam being-regularly separated by partings of shale, clunch, or smut; and are of a generally uniform character over the whole of the district, varying more or less in thickness, and influencing more or less the total thickness of the seam of coal.

A certain local nomenclature by which these divisions of the Thick coal are distinguished has been adopted by the colliers, varying somewhat in each of the two districts, which is shown by the sections of the Thick coal given in Tables I to IV (appended) and in Figs. 12 to 15 , Plate 23 ; the three first taken in the western district, and the 
fourth in the eastern, giving the thickness of each division of coal and of the partings separating them. Rude and unmusical as the nomenclature in these tables sounds, it has at least the authority of antiquity to support it; for so far back as 1665 Dud Dudley, whose name is conspicuously eminent as an authority on the making of pig iron from pit coal, refers to similar terms of designation as then in use. He mentions that "the three uppermost measures are called the white measures, from the white arsenical salsuginous and sulphurous substance which is in them; and the next measures are the shoulder coal, the toe coal, the foot coal, the yard coal, the slipper coal, the sawyer coal, and the frizzly coal : the last three coals being the best for the making of iron, though other coals may be made use of."

The character of the coal in these several divisions and the greater or less thickness of the partings materially influence the cast of getting the Thick coal, as well as its marketable value, which is subject to great variations under the same or nearly the same conditions of the market. Hitherto this coal has been found of the highest excellence on the northern extremity of the basin; and it is there that the earliest workings commenced, partly by reason of its accessibility, but chiefly from the excellence of its quality at the outcrop. In that portion of the district lying between Wednesbury and Bilston on each side of the main north road, known as Wednesbury Old Field and King's Heath, the restiges of old workings which are known to have been in operation as early as the year 1315 are spread over a large area. In 1577 deaths are recorded of men killed in the coal pits at Wednesbury. The method of working appears to have been by means of what are called "bell pits," in which after the pits were sunk the coal was excarated as far round the bottom of the shaft as could be done with safety; and when all the coal that could be thus worked was abstracted, other pits were sunk and subjected to the same process. As the coal was shallow and the sinking therefore inexpensive, the cost of getting by this mode was very moderate. Plot in his history of Staffordshire (1686) speaks thus of the coal in this locality:- "The smithies and kitchen fires are much better supplied by the common coal of the country, especially that of Wednesbury, Dudley, and Sedgley, which some prefer to the Cannel itself; the 
texture and other qualities being such that it is a flat shining coal, having a pretty open grain, lying seldom level with the plane of the horizon but most times somewhat inclining to it, according to which it cleaves into blocks at the discretion of the workman; and it burns away with a sweet bright flame and into white ashes, leaving no such cinder as that from Newcastle-on-Tyne: the beds lying sometimes ten, eleven, or twelve yards thick; nay, I was told that at Ettingshall, in a place called Moorfields, the bed of coal is fourteen yards thick;

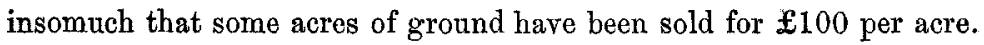
I was informed of one acre that sold for $£ 150$, and well indeed it might be so, for out of one single shaft there have been sometimes drawn

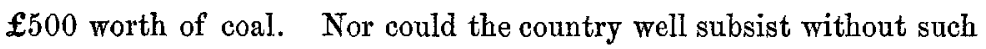
vast supplies, the wood being most of it spent upon the ironworks; for it is here, as well as in other countries that fetch their winter supply from hence, thought not only fit for the kitchen, but all other offices, even to the parlour and bedchamber; and not only in private families, but now too in most if not all the mechanic professions (except the ironworks) that require the greatest expense of fuel, as the glass houses, salt works, brick making, and malting, all of which were heretofore performed with wood or charcoal, especially the last, which one would think should hardly admit of the unpleasant fumes of such firing; nor indeed does it, no more than of wood, for they have a way of charring it in all particulars as they do wood, whence the coal is freed from those noxious steams that would otherwise give the malt an ill odour. The coal thus prepared they call cokes, which conceives as strong a heat almost as charcoal itself, and is as fit for most other uses, but for melting, fining and refining iron which it cannot be brought to do, although attempted by the most skilful and curious artists." The invention of the steam engine, and its application to the process of pumping the water from the mines, soon placed this rich district under more extensive requisition: and the excellent quality of the coal commanded for many years a high price in the market; for household purposes the celebrated Wednesbury Thick coal being noted far and wide. In addition to these ancient Wednesbury workings, the coals of which do not at this period appear to have been applied in any way to the manufacture of iron, operations in the Thick coal were carried on 
to some extent on Pensnett Chase, in the western portion of the district; and it was in this locality that Dud Dudley tried his first experiments in iron making. He says, writing in 1665:-"There are at least within ten miles of the castle of Dudley twelve or fourteen coal works, some in Worcestershire and some in Staffordshire, now in work, and twice as many not in work; each of which gets two thousand tons of coal yearly, and some three, four, or five thousand tons of coal yearly: and the uppermost or top measures of coal are ten, eleven, and some twelve yards thick; the coal ascending, basseting, or cropping up to the surface of the earth, and there the colliers formerly got it; but where the coal is deep and but little earth upon it, there the colliers rid off the earth and dig the coal under their feet; these works are called 'foot rids.'"

There is a marked distinction in the mineralogical character of the Thick coal in the two portions of the district. In the Wednesbury district the coal in the greater portion of the beds is generally of a more compact and crystalline character, breaking up into large cubical fragments, burning with a strong heat and leaving a comparatively small residuum of ash. It is therefore better adapted for domestic use or gas making, and commands in consequence a higher selling price. An exception must be made however in respect of the coal in the Oldbury district, where, owing probably to the proximity of the basalt of the Rowley Ridge on the west and the red sandstone fault of Westbromwich on the east, the quality is much deteriorated, the coal possessing neither the requisites of a good house coal nor suitability for iron smelting, and reaching therefore searcely half the value per acre of the same seam in the Wednesbury district. In the region west of Dudley, although the qualities ascribed to the Wednesbury coal attach in some degree to a portion of the Thick coal, yet generally speaking it has a more dark and earthy texture, breaking with a tough and fibrous rather than with a short and granular fracture, and exhibiting clearer indications of vegetable origin. It is therefore better adapted for iron smelting, and has been held in higher estimation for that purpose from the days of Dud Dudley downwards : the pig iron made there being generally better in quality from the same ores where this coal is used. 
III. Modes of Working the Thick Coal, and methods of Ventilation.

Enough has perhaps been stated now to give a fair idea of the situation and geological conditions of the Thick coal ; and guarded as it is by the spirits of earth, air, and water, it remains to be considered how to attack and win this golden fleece.

For this purpose any given area may be taken, say 20 acres, included within any of the known faults which have been ascertained and laid down with so much accuracy by Mr. Jukes. The first step will naturally be to ascertain the inclination or dip of the coal, and the probable extent of water to be encountered; and then to mark out the proper site for two or three shafts. This done, it is necessary to erect a steam engine of the requisite power not only to wind up the coal from any probable depth when won, but also to pump whatever quantity of water the mine may yield. Two shafts are usually sunk of 7 or 8 feet diameter and about 24 feet apart, which are ventilated by drifts from one to the other as the sinking proceeds. In case of much water being found, a third shaft is sunk, into which the water from the other two is conducted and purnped up to the surface; or else the water is coffered out with brickwork, which serves the same purpose as iron tubbing, whereby the water is stopped back to prevent it flowing into the shafts at all. It is usual to sink one of the shafts a little lower than the coal, as shown in Figs. 5 and 6, Plate 19, to provide what is called "sump room" or space to hold any small accumulations of water the mine may yield; from which, when there is no need for a pumping apparatus, the water is drawn by barrels as often as requisite. For rentilation one of the shafts is appropriated as a downcast, through which the fresh air enters the mine; and the other is the upcast shaft, up which the vitiated air that has passed through the workings is conducted; and a communication closed by doors is made between the two shafts. When all is completed relating to the shafts, and a stable for the horses excavated in the cal near the bottom, the next process is driving out the gate roads along which the coal is conveyed, and the air heads through which the foul air is brought back from the workings to the upcast shaft. 
The gate roads, Figs. 5 and 7 , Plates 19 and 20, are cut 9 feet high and 9 feet wide; and this is effected by the pikeman undergoing or catting the coal horizontally at the bottom, excavating $4 \frac{1}{2}$ feet inwards 8 feet in width, making 36 square feet by 18 inches thick, for a "stinf" or day's work. This bottom cutting or undergoing is carried inwards some 15 or 18 feet, of the width of the gate road, 9 feet. One side is then cut up 18 inches thick to the top of the Slipper coal (see the sections of the Thick coal in Figs. 12 to 15, Plate 23, and Tables I to $I V$ appended), in stints of 3 feet vertically and 12 feet inwards, making 36 square feet per day; and this done, the coal is broken down from the fast side by mechanical means, wedge or gunpowder, and removed by the various workmen. The air head is driven at the same time, generally in the Tow coal, the fourth seam from the top; and a communication is made from it to the upcast shaft. The dimensions of the air head are about 4 feet high by 4 feet wide, giving a sectional area of about 16 square feet. It is usual to drive two gate roads, one from each shaft, in the same or in opposite directions, the air heads from each being conducted to the upcast shaft. When the two gate roads are driven in the same direction and the mine is tolerably free from gas, the ventilation is effected by the gate roads alone, and the use of the air heads is dispensed with. Communications or " spouts" are made at certain intervals between the air head and the gate road, so that a proper supply of fresh air may always be secured close up to the spot at which the workmen are employed, an attention to which is of great importance.

When the gate roads are completed, the next process is to open off the work, and in this operation arrangements are made for getting out as large an area of coal in each panel or "side of work" as is practicable. This is more or less controlled by the nature of the coal, and the quantity of rubbish, technically called "gob," to be left behind in the pits as worthless, which from its tendency to heat by the decomposition of the iron pyrites contained in it renders the risk of fire more or less imminent. In opening off, the first step in the ordinary "Rib and Pillar" system of working, shown in section and plan in Figs. 5 and 7, Plates 19 and 20, is to drive two lateral openings about 9 feet wide, called "bolt holes," about 100 feet apart, 
of a length equal to the proposed thickness of the rib intended to be left as a support on each side of the gate road, usually about 30 feet. The process of undergoing the coal is then commenced, for which lengths of about 30 feet are marked off for working space, leaving alternate intervals of 24 to 30 feet as pillars for the support of the roof ; and this marking off is repeated according to the number of pillars it is proposed the "side of work" should contain. The mode of undergoing is the same as that described in driving the gate roads; four or five men working in a row and in a horizontal position, each excavating 6 feet by 6 feet or 36 square feet horizontally and 18 inches thickness for a "stint" or day's work. The successive stints are shown in the plan, Fig. 7, Plate 20, by the dotted lines at AA. A square of 6 feet in the middle of each space of 30 feet thus undergone is then underbuilt, partly with timber packings; on which is left a minor pillar, or " man of war" or "cog," which is eventually taken away, but which serves temporarily to support the coal in the opening over the men. The cogs are underbuilt with timber in order to admit of a slight settling taking place, which renders them less liable to split or be thrown out of place by the superincumbent weight. When the undergoing has been carried in 15 or 18 feet, the second process of cutting through the Slipper coal vertically on one side is effected, 12 feet inwards by 3 feet height and 18 inches thickness being cut for a day's work. The coal being set at liberty on the side so cut is broken off on the other by wedging or blasting, and then removed by subordinate workmen attendant on another class of men called the " bondsmen," whose business it is to load the coal on to the skips or carriages by which it is conveyed on railways to the pit's bottom. The next process is to cut the third section of coal, the Sawyer and Patehels coals, which is effected in a similar manner, as shown at B, Fig. 5, Plate 19, and in the sections of Thick coal, Tables I to IV; and so on to the fourth cutting in the Stone coal C, Fig. 5. This completes the cutting of the bottom coals, which are then broken down and removed. The upper portions of the bottom coals are reached by raising the floor with the slack and refuse produced in cutting the lowest measures. The cuttings are made round the pillars and $\operatorname{cog} s$, as shown in the section, Fig. 5, Plate 19. 
The fifth cutting D, Fig. 5, Plate 19, begins the top series of coals, and is in the Veins and Fine coals, which are reached by means of a scaffold. Here commences the most hazardous part of the process : the underbuilding of the cogs is then removed, and the cogs themselves come down throughout the entire height of the coals recently cut: the remainder of the coals uncut, being thus deprived of their support in the centre, deflect, or in the language of the collier "swag," and occasionally fall down more or less suddenly without further interference. Their tendency to fall is tested by the overman from time to time by tapping them in various places with the pike. When the cogs are removed the floor of the mine usually "creeps" or is forced upwards by the pressure of the permament pillars, as shown in the section, Fig. 5 ; which affords greater facilities for reaching the upper coals in the further process of cutting in. If the upper coals have not already fallen, the sixth cutting is made in the Brazils coal, the seventh in the Tow coal $\mathrm{E}$, Fig. 5, and the eighth in the White coal, as at F. During the cutting, the top coal is partially supported by wooden spirns or wedges driven upwards into the cuttings, which are withdrawn as soon as the preparations for falling the coals are completed. The remaining measures, namely the Spires and Roof coals, are seldom cut, or if cut at all only half through, and are eventually forced down by the workman acting upon them with a long pole armed with a strong pricker. In cases where the measures immediately above the coal are weak and friable, the top measure of coal is left for a roof. At this stage of the proceedings it is necessary to remove the gob or rubbish, which by this time is beginning to heat; the larger fragments are piled round the permanent pillars, as shown in Fig. 5, which they serve to support in some degree, and the small is distributed by boys about the floor of the mine. When all the coals, excepting the pillars permanently left, are thus removed from each panel or side of work, and as large an area worked as is consistent with safety, which may vary from four to ten pillars according to the character of the coal, dams or air-tight stoppings are built in the bolt holes, to prevent fire by cutting off all communication with the external air.

It is in cutting in the top series of coals that the danger to the collier chiefly arises; and it is only to men of experience, vigilance, 
and activity, that this department should be entrusted, the coal often coming down before the cutting is completed : usually however giving some previous warning by a peculiar crackling sound, which the men instantly recognise and hastily quit the scaffold and retreat to some place of safety. In addition to this special source of danger, great risk is further occasioned by the extensive oocurrence in the Thick coal of numerous dislocations called "slips" and "things," with which the whole seam is reticulated, and which form natural partings that the workmen have no previous knowledge of. When these are intersected in cutting the coals, it frequently happens that the coals fall without any warning, and the unfortunate workman is crushed beneath them. The records of the loss of life from this cause place South Staffordshire in a melancholy pre-eminence in comparison with other districts, as will be seen by Table V (appended), compiled by Mr. Greenwell, of Radstock, Bath, from the reports of Government Inspectors of Mines and from Mr. Hunt's Mineral Statistics.

During the process of working, the ventilation is effected by earrying on the air heads into the side of work as high in the coal as may be found needful to clear the upper part of the work of any gas that may be given out: the fresh air traversing the gate road and through the bolt hole and circulating freely round the part of the work where the men are employed, making its exit by the air head into the upcast shaft, as shown by the arrows in the plan, Fig. 7, Plate 20. Some practical difficulty arises from the occasional tendency of the current of air to stagnate or to reverse itself, to which it is more subject in hot weather, when the temperature of the mine and that of the external air become more equalised. The pits are then said to fight, and this can be remedied only by increasing the temperature of the upcast shaft artificially by a furnace connected with it, to stimulate the draught. At ordinary temperatures of the atmosphere however the bigher degree of heat in the working places of the mine, usually from $65^{\circ}$ to $70^{\circ}$, is itself sufficient to keep the current of air in motion at the rate of about 30 feet per second in the gate roads, and in the air heads at about 120 feet per second; which affords an abundant supply of fresh air for the effictent ventilation of as many sides of work as can be kept open at a time. 
Now two cardinal points demand attention and enquiry in reference to this rib and pillar mode of working the Thick coal :-first, the apparently imperfect mode of ventilation; and secondly, the inadequate produce of coal per acre, considering the thickness of the seam.

As to the first, imperfect in some respects as the method of ventilation certainly is, it has not hitherto been found practicable to adopt any plan more effective; and on the whole very little complaint has to be made under this mode of working the Thick coal, with the ordinary vigilance which it is incumbent on. every manager of a mine to exercise. Other plans have been devised and partially acted upon, but they have not become satisfactorily established. One only of these may be briefly described, chiefly on account of its having been originally promulgated by Mr. B. Gibbons of Shat End, whose name as connected with both the iron and coal trades bears an authority of the highest eharacter, no two men having initiated improvements of a more beneficial nature to those trades than this gentleman and his brother, the late Mr. John Gibbons. In this plan of ventilation, instead of fresh air being supplied to the workings by means of the upcast and downcast shafts in the ordinary mode, each shaft is made to ventilate its own workings by the addition to the shaft of what is called a " trumpeting" or smaller supplementary shaft, as shown in Fig. 11, Plate 22; in connexion with which a ventilating furnace and chimney are erected at the surface for the purpose of artificially inereasing the natural draught of the pit. It will be seen that this trumpeting is a substitute for the ordinary upcast shaft; and the ohief objections to it are, first, its original expense, which, if it is made sufficiently capacious to be effective, is nearly equal to that of a separate upcast shaft; and secondly, its limited dimensions and consequent liability to derangement. These objections have deterred the practical managers of mines in South Staffordshire from adopting the plan.

In the present state of the Thick cosl seam, the risk of accident from fire damp is far less than that when mining operations first commenced in it. The carburetted hydrogen gas, in which it is so prolifie, escapes wherever any incision is made in the coal by which a vertical section of its lamine is exposed to the air. This may be readily 
tested by the application of a candle to the portion of coal cut through in sinking the shaft, when flashes of ignited carburetted hydrogen gas, which escapes with a singing noise, occur wherever it comes in contact with the flame. The great extent to which the Thick coal is now cut up in all directions affords such abundant channels of escape for this gas, that the enemy, which was formerly so dangerous to encounter and difficult to subdue, is now by the aid of the safety lamp controlled with comparative ease. Before however the ventilation by the present system of high air heads and the use of the safety lamp were established, devices for dissipating the gas were adopted which would now be considered unjustifiably dangerous. Plot in his history of Staffordshire (1686), speaking of the mode of working the mines near Wednesbury, describes the mode of ventilation thus :- "In working the mine much inconvenience is experienced by the presence of damp. One sort is expelled either by water, or by letting down an iron cradle, as they call their lamp, filled with fire, into the shaft or the bye pit next to that they intend to work; which making a draught draws away the foul air. Another sort is expelled by a person entering the pit before the workmen, covered with wet sackcloth; when he comes near where the damp is feared, he creeps on his belly with a long pole before him having a lighted candle upon the top of it; which coming in contact with the foul air, it explodes and escapes by the mouth of the pit, the person that fired it escaping by creeping on the ground, keeping his face close to it till it is over." Even down to modern times, schemes as daring and hazardons as that described were the common resource in many parts of South Staffordshire. In the Netherton district, south west of Dudley, the coal in the early part of the present century was rendered almost unworkable from the abundance of this gas, which set at defiance any of the then known modes of working. The ventilation was effected by a current of air travelling the gate roads alone by the down and upcast shafts, the roads themselves being ventilated during the process of driving by side air heads or troughs; but the escape of gas was so abundant that even in the roads the air could scarcely be kept below the inflammable point. In all those portions of the mine therefore above the level of the gate roads the gas naturally accumulated in excessive quantities, 
and it was a troublesome as well as a dangerous process to clear the mine in the morning of the accumulation of the previous night. This was usually done by exploding the gas by means of the firing line, which was a contrivance for raising a lighted candle into the higher parts of the mine by means of a pulley and string fastened to the top of a pole, by which the candle was gradually drawn up by the fireman, who with his assistants was ensconced in some place of safety adjoining and thus exploded the gas. It is needless to enlarge on the danger, inconvenience, and lamentable loss of life and waste of property which were involved in this process. Nevertheless it was the only mode by which the working of these fiery mines could be conducted in the existing state of mining knowledge at that period. It was not until about the year 1810 that any material improvement was effected, when a mining engineer named John Ryan, an Irishman, made his appesance in that district and profered his services to free the fiery mines in the neighbourhood of Netherton from fire damp, at least to such an extent as to make them comparatively safe to work. Whether he redeemed this pledge to the full extent of his professions is doubtful; but it is certain that he effected very considerable improvement in the rentilation. His plan was to surround the workings with a separate air head carried up high in the coal, into which all the foul air and inflammable gas were conducted and carried to the upcast shaft: and although it was found that the requisite conditions in the coal for carrying out this plan in its integrity could not be met with in practice, yet modifications of it were adopted, and the present mode of ventilation is unquestionably the offspring of his genius. The courage and perseverance with which Mr. Ryan prosecuted his system were deserving of the highest praise, and the danger which he personally encountered and the resolution which he displayed were such that he was familiarly known among the colliers by the name of " hell-fire Jack." He may be remembered by many coal owners of the present generation by the importunity with which he continually urged upon them the righteousness of coroner's juries finding a verdict of wilful murder in all cases of deaths from explosions in those collieries in which his system of ventilation was not acted upon. The introduetion about the year 1815 of the safety lamp of Sir H. Dary into 
mines of a fiery character was an invaluable aid both as regards the safety of life and the practical facility of working. By its use not only was the presence of the enemy detected, but it admitted of means being adopted by the workman for dissipating the gas under circumstances that were quite impracticable with a naked light; and it may be safely said that no greater boon has been conferred on mankind than that which has been given by this admirable invention to the miner.

Whilst however it is the business of the manager of a Thick coal mine to adopt measures for ample ventilation, some precautions are necessary against a too abundant supply of fresh air, by which the natural tendency of the gob to fire is greatly increased; and in avoiding Scylla therefore care must be taken not to run foul of Charybdis. This is one of the difficulties of the miner's craft, and one with which the earliest miners had to contend. "These small coals," writes Dud Dudley in 1665, "produce often great prejudice to the owners of the works and to the work itself, and also to the colliers, who cast the small coals together; which compelling necessity forces the colliers to do for two causes: one is to raise them to cut down the ten yards thickness of coals, of which they draw only the bigger sort of coal, not regarding the lesser or small coal which will bring no money, saying ' he that liveth longest let him fetch fire further :' next, the colliers must cast these small coals and slack or dross out of their way, which sulphurous small coal and crowded moist slack heat naturally and kindle in the middle of those great heaps, often setting the coal works on fire and flaming out of the pits and continuing burning like Etna or Hecla." It is the duty of a prudent miner to leave as little refuse forming the gob as possible in each side of work; and if it fire, to have the work sufficiently at command to be able immediately to exclude the fresh air by the erection of dams in the bolt holes or entrances to the side of work, and thus extinguish the fire by depriving it of air.

The second point demanding attention,- the insufficient produce of Thick coal per acre,-has long been a source of perplexity to the enquirer. A seam of Thick coal 10 yards thick contains 48400 cubic yards per acre, each cubic yard weighing 1 ton of 2240 lbs., making 48400 tons per acre; - and deducting one fifth for partings and spoil, 
38720 tons of clear coal are left as the produce of one acre. But the first working by the rib and pillar system already described does not usually produce more than about 15000 to 16000 tons per acre; rarely more, frequently less. This produce however represents the usual nominal selling tons by boats and otherwise, prescribed by leases and the custom of the trade, of which it is difficult to define the exact weight; also the coal allowed to colliers and the small coal consumed at the steam engine, of which no account is taken, have to be added : and these together will bring up the actual produce to probably little short of 19000 or 20000 statute tons per acre. To this has to be added the produce of the after working of the ribs and pillars, which is a much more expensive and yet distant process; which will bring the total produce probably to 23000 statute tons per acre, a quantity however much less than that produced by the other mode of working called the "Long Wall" system.

In the "Long Wall" system of working, the Thick coal seam is divided into two workings, of such a thickness each as will admit of the whole of the coal in each division being cleared out, instead of leaving ribs and pillars as by the rib and pillar system previously described; the top portion being worked first. The mode of working is shown in section and plan in Figs. 6 and 8, Plates 19 and 21. The driving out of the gate roads is effected as in the rib and pillar system, and one or more main gate roads are carried forward from the shaft to the outside of the portion of coal proposed to be worked, usually in the Brazils measure about 16 feet from the top of the seam (see the section in Fig. 14, Plate 23, and Table III appended). On arriving at the outside boundary, lateral openings are made right and left of the road, and driven along sufficiently far until space is gained for the commencement of a regular face of work. The holing or undergoing is then begun, and the coal cut and broken down progressively, the colliers working back towards the shaft, and "leaving," as they describe it, " all their troubles behind them." At the outset of the operation it is necessary to cut the coal vertically in the manner previously described in the rib and pillar system; but the "shut," or the part of the roof left behind, soon begins to break down, and the coal over the holing comes down of its own accord; by leaving 
cogs behind them the workmen protect themselves against any premature fall of the roof, until it can be allowed to come down without danger. "In this manner," says Mr. Brough, "they keep sweeping fine sides of work homewards, just as the mowers sweep away swathes of grass in a hayfield. The rock or shut follows them, and with it they build the most useful fortifications in the world. Thus with a face of coal in front, so spragged (underbuilt) that all danger is ont of the question, and a building behind them as strong as a castle, it would be surprising indeed if the workmen got the slightest hurt, much more lost their lives." When the whole upper portion of the coal has been thus abstracted, the bottom portion is worked in the same manner; a few feet of coal being left in the middle of the seam to serve as a roof for the lower working. The ventilation of the working is shown by the arrows in the plan, Fig. 8, Plate 21.

It must be admitted that in point of safety to the men, as well as in the larger produce of coal per acre, the long wall has a manifest advantage over the rib and pillar system. The ventilation is perfect, the current being kept in a continual stream along the working face, with very little liability to disturbance: and the produce of coal on a moderate estimate is from 5000 to 7000 tons per acre more than in the rib and pillar system. On the comparative advantages of these two modes of working the Thick coal a great deal has been said and written both by coal owners, professional viewers, and mine inspectors; but many of the special circumstances that determine either mode in any particular instance have either been ignored or overlooked. It is beyond question that by the rib and pillar system a certain loss of coal is involved compared with the long wall system: but it must be borne in mind that the value of the Thick coal depends mainly on the size in which it can be sent into the market, the selling price gradually decreasing with the bulk, so as to afford a range of from (say) 10s. to $2 s$. per ton in coal of the same quality; a distingtion quite unknown in the bituminous coal of the North of England. Now if a much greater proportion of large coal at the higher selling prices and less of the small coal or slack at the lower selling prices can be obtained by the rib and pillar system, it may happen, and in fact does frequently 
happen, that the pecuniary value of the smaller product per acre may exceed that of the larger: and inasmuch as the royalty is usually based on the selling price per ton, it is the proprietor's interest to have that mode of mining adopted which will yield him the largest return per acre. Hence in most of the leases under which the Thick coal is worked there is en express stipulation that the system of mining shall be restricted to the ordinary rib and pillar mode of working. It is true that, owing to the increased demand of the ironworks for the rough slack used at the puddling and blast furnaces, the price of this description of coal has approximated of late much more closely to that of the large coal than was formerly the case; and greater latitude is consequently allowed for the adoption of any improved mode of working. But it must be borne in mind that many conditions are requisite to admit of the long wall system being adopted: such as ample extent of mining ground, absence of faults, facility for consumption of the coal in all shapes, and freedom from legal restrictions; a combination of advantages rarely attainable. It is but justice therefore to the character of South Staffordshire to say that, in some of the larger undertakings in the western portion of the district where these conditions are met with, improved modes of working have been long in use. A reference however to the sections of the coalfield in Figs. 2, 3, and 4, Plates 17 and 18, will show the dislocated and irregular character of the Thick coal throughout the district, of which an instance is shown in Fig. 9, Plate 22, exhibiting the position of the Thick coal in one of the Corbyn's Hall Collieries ; a disturbed condition of the seam by no means infrequent. In such cases the adoption of the long wall system or indeed of any regular system is quite impracticable, the mode of working being influenced by the actual condition and form of the seam.

IV, Area of Thiek Coal remaining unworked, and its probable duration at the present rate of working.

As regards this final branch of the subject, thene is of course considerable difficulty in obtaining suffieient data to admit of accurate calculation ; and any estimate framed on such data are within reach must therefore be to a certain extent vague. All that can be done is 
to ascertain from the most authentic sources the area unworked in each portion of the district, the weekly or annual quantity of coal got, and the number of tons each acre is considered to yield : this will give the total number of tons remaining in each portion, and hence the period of duration.

In the eastern portion of the district the extent of Thick coal remaining unworked may be estimated at about 1160 acres, yielding in the first and second workings about 20,000 tons per acre, making a total of $23,200,000$ tons. The present rate of working is about 11,000 tons per week, which for 50 working weeks amounts to 550,000 tons per annum. The probable period of duration is therefore about 42 years.

There is more difficulty in framing an estimate for the western portion of the district, owing firstly to the larger area unworked, and secondly to the absence of proof of the actual extent of the Thick coal in a southerly direction. The estimate is therefore confined to the limits previously mentioned as proved in that direction, namely from Stourbridge to Halesowen. With this limitation the area unworked is estimated at about 2785 acres, which at 20,000 tons per acre gives $55,700,000$ tons. The present rate of working is about 30,000 tons per week, or 1,500,000 tons per annum. The probable period of duration is therefore about 37 years.

It will be obvious that the respective periods of duration here given will be materially modified by the greater or less rapidity with which the present workings are carried on, and still more by the extent of the area under which the coal may eventually be found to extend in the unproved portion of the district southwards. It is certainly reasonable to infer on every geological presumption that a large extent of Thick coal may yet be available for future working which is altogether excluded from this estimate. It may however be assumed that at the expiration of another half century this noble seam of coal, the pride and glory of South Staffordshire, will exist only in name: and the future importance of this busy hive of industry must be sought in other resources than that which has hitherto contributed so largely to its strength and prosperity. 
TABLE I.

Section of Thick Coal

at Corbyn's Hall Colliery, Kingswinford.

Western district.

Rib and Pillar system of Working.

Fig. 12, Plate 23.

Partings. Coal.

Feet. Ing. Feet. Ins.

TOP COALS.

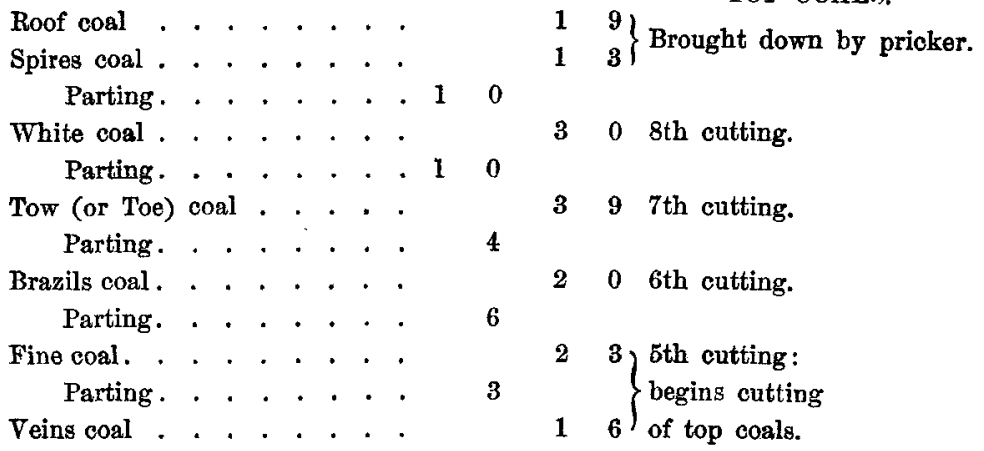

$\left.\begin{array}{ll}1 & 9 \\ 1 & 3\end{array}\right\}$ Brought down by pricker.

30 8th cutting.

$3 \quad 9 \quad 7$ th cutting.

$2 \quad 0 \quad 6$ th cutting.

$\left.\begin{array}{ll}2 & 3 \\ 1 & 6\end{array}\right\} \begin{aligned} & \text { 5th cutting: } \\ & \text { begins outting } \\ & \text { of top coals. }\end{aligned}$

Parting, Hard or Stone coal

Stone coal

Parting.

Patchels coal . . . . . .

Parting.

Sawyer coal

Parting.

Slipper coal

Parting .

Benches coal or Kid coal

Total thickness of Coal

Total thickness of Partings $4 \quad 10$

Total thickness of Seam
BOTTOM COALS.

4

$3 \quad 6\left\{\begin{array}{l}\text { 4th cutting: } \\ \text { completes cutting } \\ \text { of bottom coals. }\end{array}\right.$

2

$\left.\begin{array}{ll}2 & 6 \\ 1 & 6\end{array}\right\} 3$ rd cutting.

30 2nd cutting.

2

20 Holing or 1st cutting. 


\section{TABLE II.}

\section{Section of Thick Coal}

at Ketley Colliery, Kingswinford.

Western distriet.

Rib and Pillar system of Working.

Fig. 13, Plate 23.

\section{Partings. Coal.}

Feet. Ins. Feet. Ins,

Flying Reed coal 5 feet thick

Parting 11 feet thickening to 90 feet

White coal

Parting . . . . . . . . 2 0

Tow (or Toe) coal . . . . . . .

Parting . . . . . . . .

Brazils coal . . . . . . . .

Parting , . . . , , .

Fine coal . . . . . . . . .

Parting . . . . , . .

Veins coal

Parting . . . . . . . 10

Stone coal

Parting . . . . . . .

Patchels coal . . . . . . . .

Parting . . . . . . . . 2

Sawyer coal . . . . . . .

Parting . . . . . . .

Slipper coal . . . . . . . . .

Parting . . . . . . . . 2

Benches coal. . . . . . .

Thickness of Coal

Thickness of Partings

Thickness of Seam
TOP COALS.

30 8th outting.

39 7th cutting.

196 th cutting.

6

20 5th cutting:

$16\} \begin{aligned} & \text { begins cutting } \\ & \text { of top coals. }\end{aligned}$

BOTTOM COATS.

$30\left\{\begin{array}{l}\text { 4th cutting: } \\ \text { completes cutting } \\ \text { of bottom coals. }\end{array}\right.$

4

2

$\left.\begin{array}{ll}2 & 6 \\ 1 & 6\end{array}\right\}$ 3rd cutting.

3

30 2nd cutting.

16 Holing or 1st cutting.

236

\section{$5 0 \longdiv { 2 8 }$}

28 ft. 6 ins. 


\title{
TABLE III.
}

\author{
Section of Thick Coal \\ at Hawn Colliery, Halesowen. \\ Western district.
}

Long Wall system of Working.

Fig. 14, Plate 23.

Partings, Coal.

Feet. Ing. Feet. Ins.

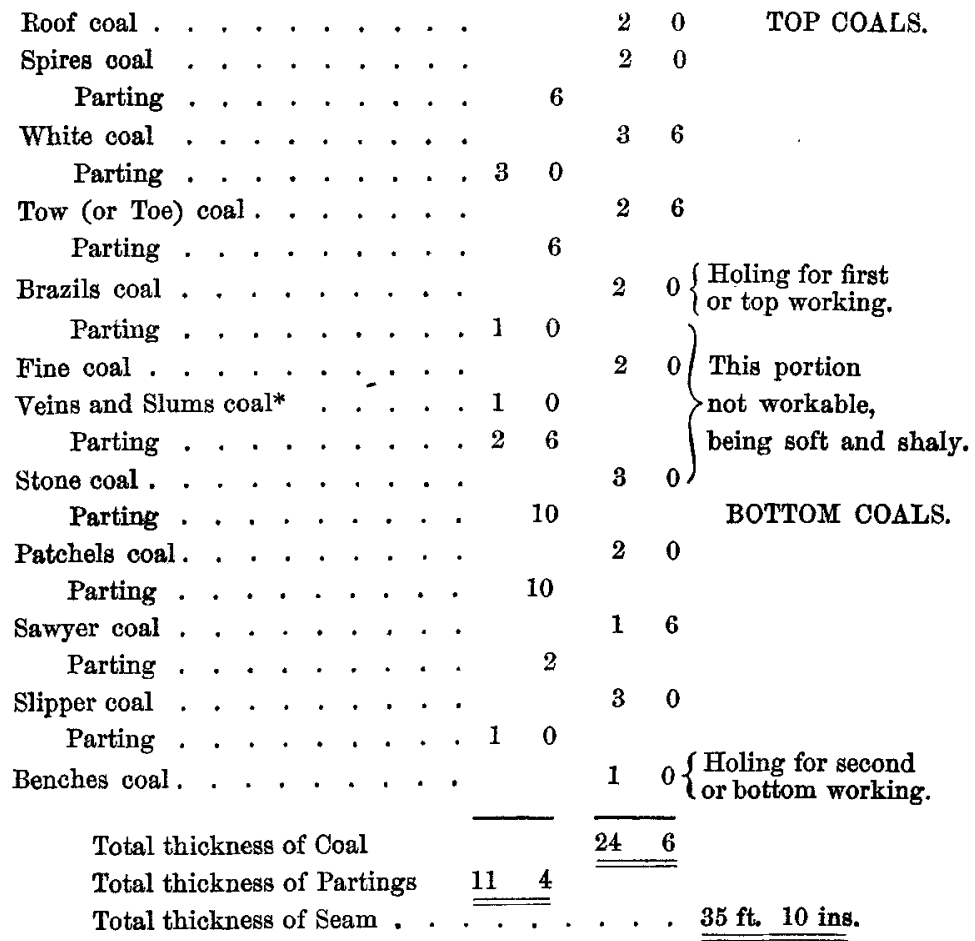

* This coal is so shaly and soft as to be worthless, so that it is no better than parting. The Veins at Corbyn's Hall are good coal, and at Ketley also. 


\author{
TABLE IV. \\ Section of Thick Coal \\ at Tividale Colliery, Rowley. \\ Eastern district. \\ Rib and Pillar system of Working.
}

Fig. 15, Plate 23.

Partings. Coal.

Feet. Ins. Feet. Ins.

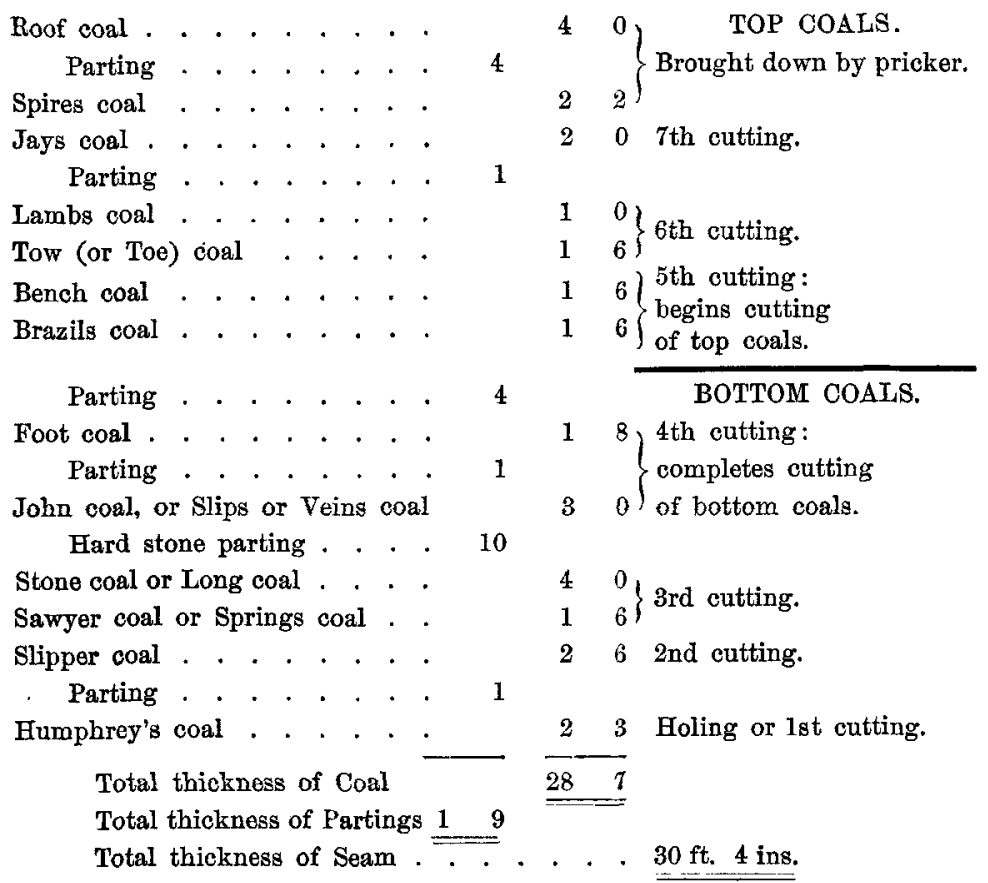




\section{TABLE V.}

Deaths by Accident in Collieries in the years 1854 to 1858.

\begin{tabular}{|c|c|c|c|c|c|c|c|c|c|c|}
\hline & \multicolumn{2}{|c|}{ Miscellaneous. } & \multicolumn{2}{|c|}{ In Shafts. } & \multicolumn{2}{|c|}{ By Falls of Coal. } & \multicolumn{2}{|c|}{ By Explosions, \&c. } & \multicolumn{2}{|c|}{ Total. } \\
\hline & $\begin{array}{c}\text { Number } \\
\text { of } \\
\text { Deaths. }\end{array}$ & $\begin{array}{l}\text { Tons of Coal } \\
\text { raised } \\
\text { per death. }\end{array}$ & $\begin{array}{c}\text { Number } \\
\text { of } \\
\text { Deatbs. }\end{array}$ & $\begin{array}{l}\text { Tons of Coal } \\
\text { raised } \\
\text { per death. }\end{array}$ & $\begin{array}{c}\text { Number } \\
\text { of } \\
\text { Deaths. }\end{array}$ & $\begin{array}{l}\text { Tons of Coal } \\
\text { raised } \\
\text { per death. }\end{array}$ & $\begin{array}{c}\text { Number } \\
\text { of } \\
\text { Deaths. }\end{array}$ & $\begin{array}{c}\text { Tons of Coal } \\
\text { raised } \\
\text { per death. }\end{array}$ & $\begin{array}{c}\text { Number } \\
\text { of } \\
\text { Deaths. }\end{array}$ & $\begin{array}{c}\text { Tons of Coal } \\
\text { raised } \\
\text { per death. }\end{array}$ \\
\hline $\begin{array}{l}\text { Northumberland, Durham, } \\
\text { and Cumberland }\end{array}$ & 269 & 306,386 & 122 & 676,209 & 263 & 313,679 & 68 & $1,213,199$ & 722 & 114,262 \\
\hline $\begin{array}{c}\text { Lancashire, Cheshire, and } \\
\text { North Wales }\end{array}$ & 162 & 325,443 & 254 & 207,566 & 291 & 181,171 & 405 & 130,177 & 1112 & 47,408 \\
\hline $\begin{array}{l}\text { York, Derby, Nottingham, } \\
\text { Leicester, and Warwick }\end{array}$ & 66 & 955,273 & 161 & 391,602 & 208 & 303,115 & 288 & 218,917 & 723 & 87,203 \\
\hline $\begin{array}{c}\text { Stafford, Worcester, and } \\
\text { Shropshire } . \cdot, \cdot \cdot\}\end{array}$ & 86 & 476,867 & 270 & 151,891 & 572 & 71,697 & 160 & 256,316 & 1088 & 37,693 \\
\hline $\left.\begin{array}{r}\text { Somersetshire, Gloucester, } \\
\text { Monmouth,\&SouthWales }\end{array}\right\}$ & 147 & 322,464 & 162 & 292,606 & 404 & 117,332 & 294 & 161,232 & 1007 & 47,072 \\
\hline Scotland. . . . . . . & 41 & 961,237 & 130 & 303,159 & 188 & 209,631 & 54 & 729,828 & 413 & 95,425 \\
\hline Total & 771 & 422,945 & 1099 & 296,716 & 1926 & 169,309 & 1269 & 256,968 & 5065 & 64,381 \\
\hline
\end{tabular}


Mr. Mathews remarked that the estimate given in the paper as to the probable duration of the Thick coal was intended only as an approximate calculation, which he had made with as much care as he was able from the following data. For the eastern side of the district he had taken the estimates of Mr. Job Taylor, Mr. Yardley, and Mr. Cooksey, who were the best authorities as to the extent of Thick coal remaining unworked in that portion of the field, and the present rate of working there. For the rest of the district he had taken the geological ordnance map, dividing the coalfield into squares of 1 mile each, and subdividing these again into quarter miles or squares of 160 acres; and had then estimated how much of the Thick coal was left in each square from his personal knowledge of the extent to which it had been already worked. The estimate in the southern portion of the district was carried only as far as the limits to which the Thick coal had at present been proved; and therefore the calculated duration applied only to the coal north of those limits, which was now in process of working.

Mr. A. B. Cochrane thought the paper just read was a most valuable and interesting one, and the members of the Institution and the South Staffordshire district in general were greatly indebted to Mr. Mathews for the trouble he had taken in preparing it ; it formed a valuable contribution to the information of the district, and he trusted it would lead to further enquiries into the subject, and improvements in the present modes of working. He fully agreed with the statements advanced in the paper, excepting in one particular, in respect to the quantity of Thick coal per acre that was raised in the district by the ordinary rib and pillar working. It was stated in the paper that the maximum quantity of Thick coal which could be raised in the first working amounted on the average throughout the district to only 16000 tons per acre, which would be increased to about 23000 tons per acre by the second working of the ribs and pillars; and that to get a greater amount it would be necessary to adopt the long wall system of working, instead of the rib and pillar working : but, thongh he himself had no experience of the long wall system, the result of his own experience with rib and pillar working was that a considerably greater quantity of the Thick coal than the amount named might be 
raised per acre with proper care in working. He thought at least as much as 23000 tons per acre might be raised by the rib and pillar system in the first working alone, and the second working of the ribs and pillars would then yield a still further quantity. The coal must of course be of good quality, to obtain such a quantity per acre, and comparatively free from faults, which interfered much with the quantity that could be raised, by preventing the coal being obtained in large pieces to so great an extent, and producing a greater quantity of slack. He was inclined to think that in point of quantity of coal raised per acre the Thick coal could be worked as satisfactorily by the rib and pillar system as by the long wall mode.

As regarded the question of relative loss of life by the two systems, he quite agreed that this ought to be a primary consideration in determining the adoption of either mode of working. The long wall system appeared certainly to be attended with less danger than the rib and pillar working, both in being more secure against sudden falls of coal, and also in allowing of better ventilation of the workings. It was almost impossible to avoid accidents occurring in the rib and pillar system from the falling of masses of coal in the process of getting, and from the ribs and pillars being crushed by the weight of the roof, in consequence of the coal being of a more friable nature in some places than others: whereas in the long wall system the roof was securely propped up with a barrier of rock behind the workmen, who were thus effectually protected against falls. When an extraordinary number of faults occurred in the coal, there would be much difficulty in winning it by the long wall system; and in such portions of the district there was therefore no alternative but to work with ribs and pillars.

Mr. Job Taylor said that at New Round's Green Colliery, the only case where he had had an opportunity of obtaining the actual result of working, the quantity of Thick coal produced by the rib and pillar system amounted to 23500 tons per acre in the first working, which was rather more than the quantity given in the paper as the average produce of both workings; and in that case the coal was only from $8 \frac{1}{2}$ to 9 yards thick, instead of the full thickness of 10 yards. This produce was the nominal weight sold, which was about 25 per cent. 
less than the actual produce, on account of the large allowance that was usual over the nominal weight. A further addition had to be made for the coal allowed to the colliers and mine owners, and the small coal consumed for the engine, besides the entire produce of the second working which had not yet been commenced; so that the total produce of the Thick coal would amount to about 30000 tons per acre. He therefore considered there was not so great a disparity in produce per acre between the two modes of working as had been represented in the paper.

From his own experience of the long wall system in other districts he did not think it was practicable for the entire seam of coal to be got even on that mode of working, as shown in the diagram: for he had found that nearly double the quantity of slack was made by the long wall working as compared with the rib and pillar, and thought it was impossible to get out the coal with safety unless a certain number of pillars were left to support the roof. In regard to risk of accidents by the long wall system as compared with the rib and pillar, he considered on the whole there were as many accidents in the long wall workings, though in a different way and probably not so frequently fatal. In undergoing the coal in the long wall system, it was liable to break down in large masses, which was avoided in the rib and pillar working where only about $2 \frac{1}{2}$ feet beight of coal was brought down in the holing at a time; but the danger in the rib and pillar working increased as the cutting was carried upwards to the top coal, and the second working of the ribs and pillars was certainly attended with greater risk of accident than the long wall system. If the long wall mode of working were adopted as shown in the diagram, it did not appear that it would be interfered with by the occurrence of faults in the coal ; but these would merely entail a little more caution upon the workmen to avoid the coal falling suddenly at the places where they occurred.

He thought the paper gave a correct representation of the district at the present time and of the mode of working the Thick coal ; it exhibited a great amount of knowledge on the subject, and showed that much time and trouble must have been spent in its preparation. 
Mr. Mathews observed that in the portion of the Thick coal worked by Mr. Taylor, where so large a produce as 23500 tons per acre had been got in the first working by the rib and pillar system, the coal was of a strong quality and. very regular in its formation; so that the workings could be carried forward quickly, and a large proportion of the entire quantity of coal in the mine was obtained in the first working. Such a case was however an exceptional one, and attended with unusually fortunate circumstances. No doubt a considerably greater produce than he had mentioned was obtained in particular instances; but he thought that, taking a general practical average, it would not be possible to get more coal per acre, unless by paring down the ribs and pillars to unduly small dimensions; and after such a first working he had great doubts as to the advantage of a second working, which could only be done to profit at a time when the price of coal was high, as the marketable value of the coal obtained from the ribs and pillars would be greatly deteriorated by the heavy pressure they had supported in the first working. He had endeavoured to deal with the average production of the district, avoiding extreme cases; and there were certainly many mines in which the produce per acre fell short of the average amount. As regarded the cost of working by the two systems, there was no doubt that the rib and pillar system was the cheapest in the first working, as it did not involve the cost of erecting supports to keep the roof up as in the long wall system; but he considered the long wall was much the safer of the two, as the workmen were constantly protected by a barrier of rock erected behind them, which secured them from any risk of the roof falling in.

Mr. J. E. Swinderc had worked the top measures of the Thick coal by the long wall system to a thickness of about 13 feet, which produced 12000 tons per acre, leaving pillars 4 yards square to support the roof, with intervals of 5 yards; this quantity would be increased to $\mathbf{1 5 0 0 0}$ tons per acre by building "cogs" of rock instead of leaving pillars to keep the roof up. At present he had not worked the lower measures, but they would probably produce 11000 or 12000 tons per acre, and the total yield would therefore be about 27000 tons per acre: the middle portion of the seam, about 6 feet thickness, being leftas a roof for the working of the lower measures. 
Mr. Mathews remarked that the quantity of coal produced per acre by different systems of working was materially affected by its friability and general texture: for in a very friable seam of coal it might happen that the ribs and pillars would become so much crushed that they would yield only rongh and fine slack, and in such a case it would not be possible to get much large coal except by the long wall system. In the Wednesbury district, where the coal was of a more hard and compact character, it stood better in the ribs and pillars, and was got in larger masses, making only a small proportion of slack.

The Charrman moved a vote of thanks to $\mathrm{Mr}$. Mathews, which was passed, for his highly interesting paper, which was particularly valuable as drawn up from the results of personal experience. It formed a companion paper to that given at a former meeting by $\mathrm{Mr}$. Nicholas Wood on the Newcastle coal district; and such communications were most important additions to the Proceedings of the Institution.

Mr. Mathews said he had much pleasure in preparing the paper, and considered it the duty of each of the members to contribute whatever information or experience he could, that would be of service to the Institution. In the South Staffordshire mining district it was particularly important that every endeavour should be made to reduce the great loss of life at present occurring, and to arrive if possible at a more satisfactory mode of working for obtaining the whole of the Thick coal.

The following paper was then read :- 
SOUTH STAFFORDSHIRE THICK COAL. $\underset{\text { Brerdzon }}{\text { Plate } 16 .}$

Pig. 1. General Plan of South Staffordshire Coalfield.

Area of Coalfield

Area of Thick Cal

Paults, blach and white irregutar bines
A Wedmesbury
B Bilston
c Sedgler Beacon
D Wresis Nest BiZL
F Ponsreet Chase
G Netherton
H Brierles Hill
1 Cradler
K Comgreares
L Cortyn's Hall Collieries
- Kettey Colliery
- Hown Colliery
P Fividate Coltiery
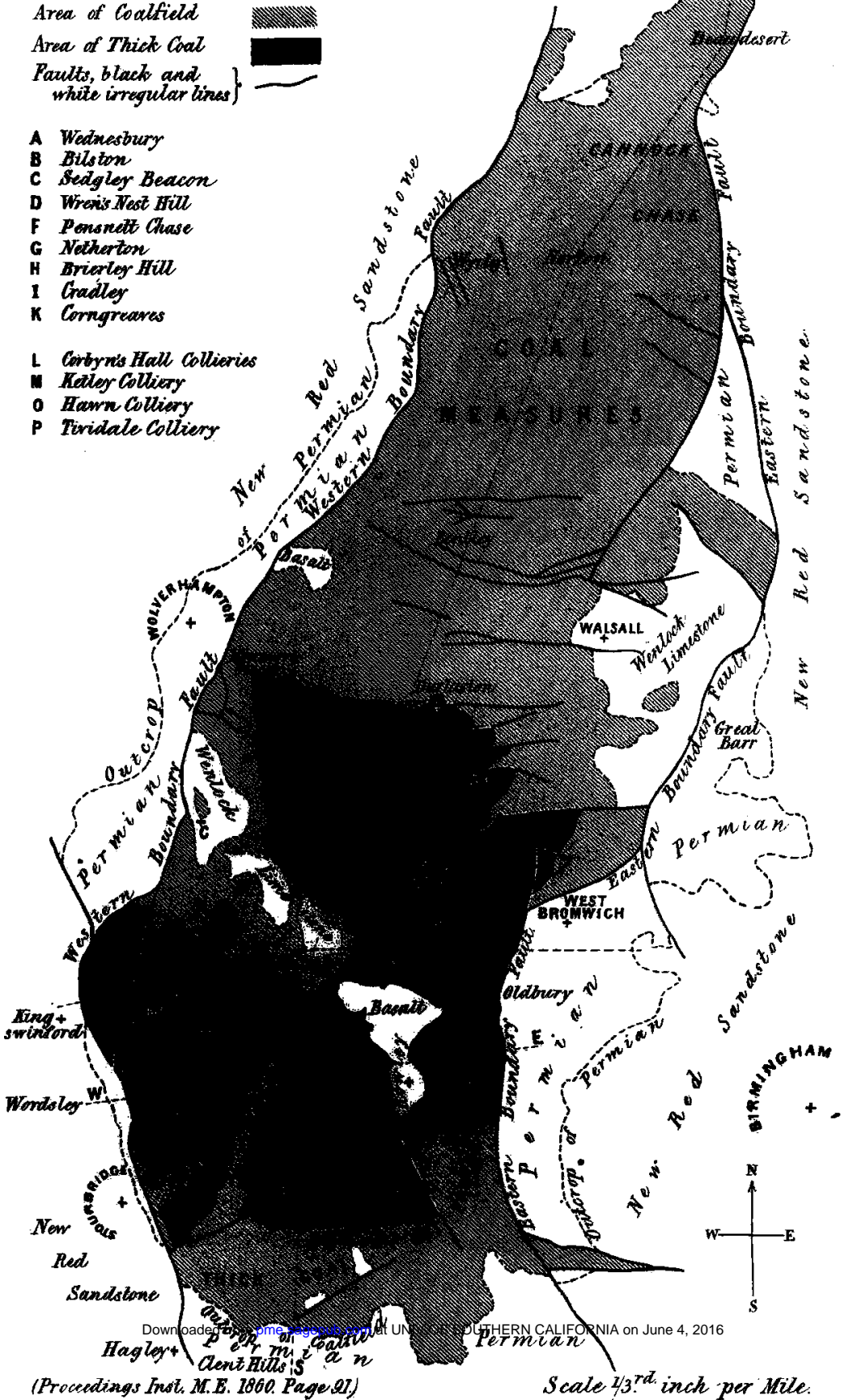


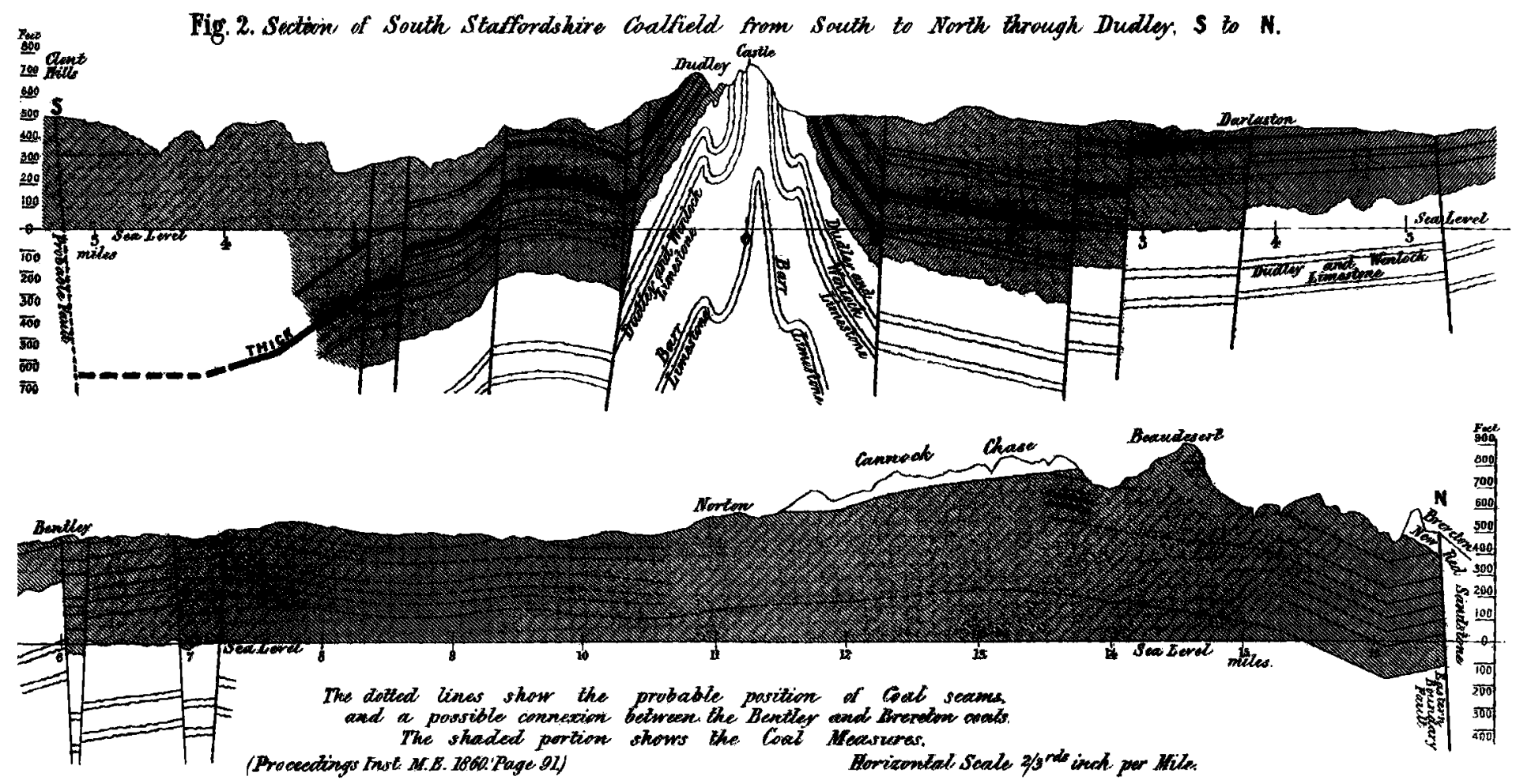


SOUTH STAFFORDSHIRE THICK COAL.

Plate 18.
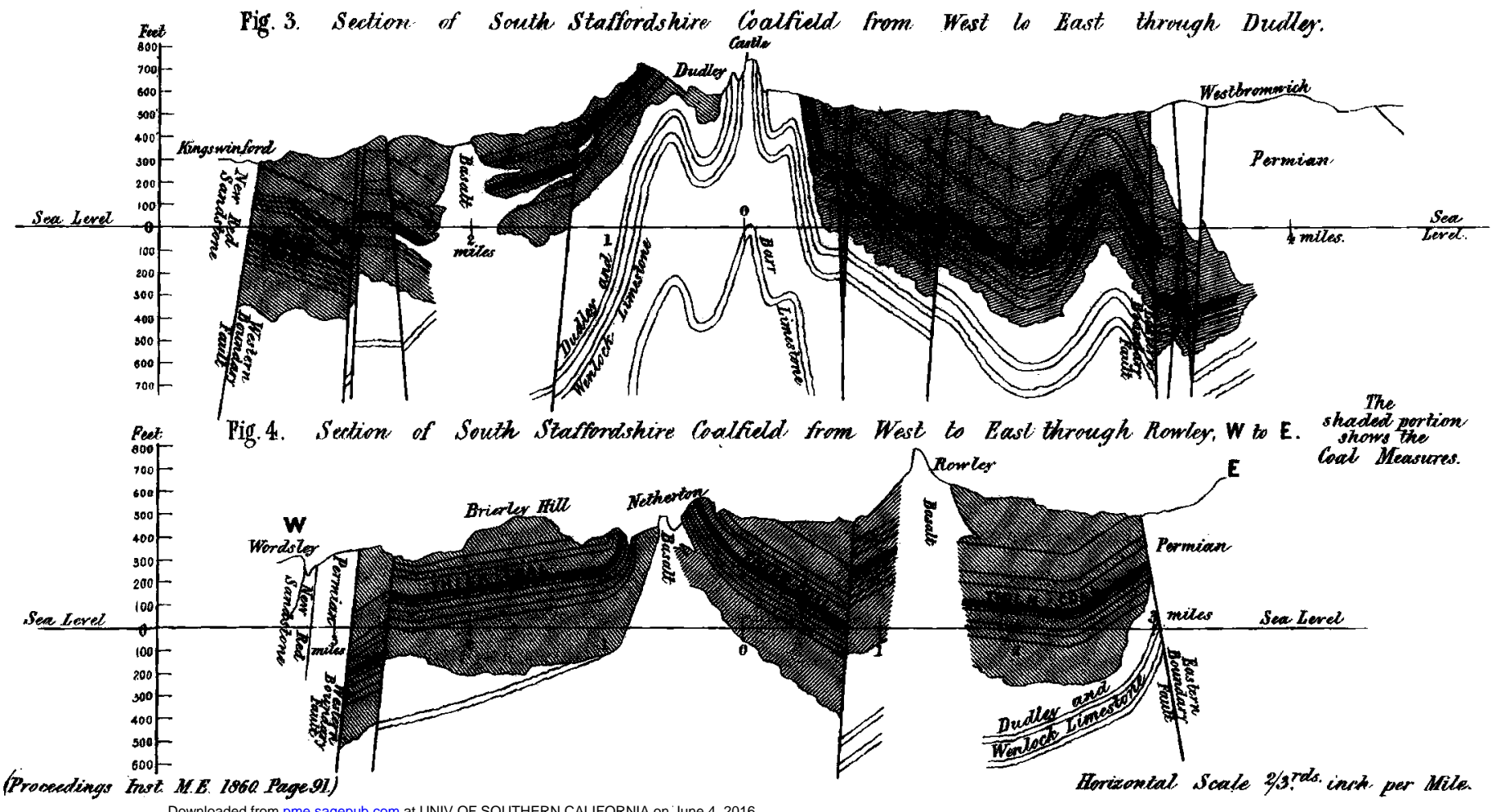
Fig. 5. Section of $R i b$ and Pillar System of Working the Thick Coal.

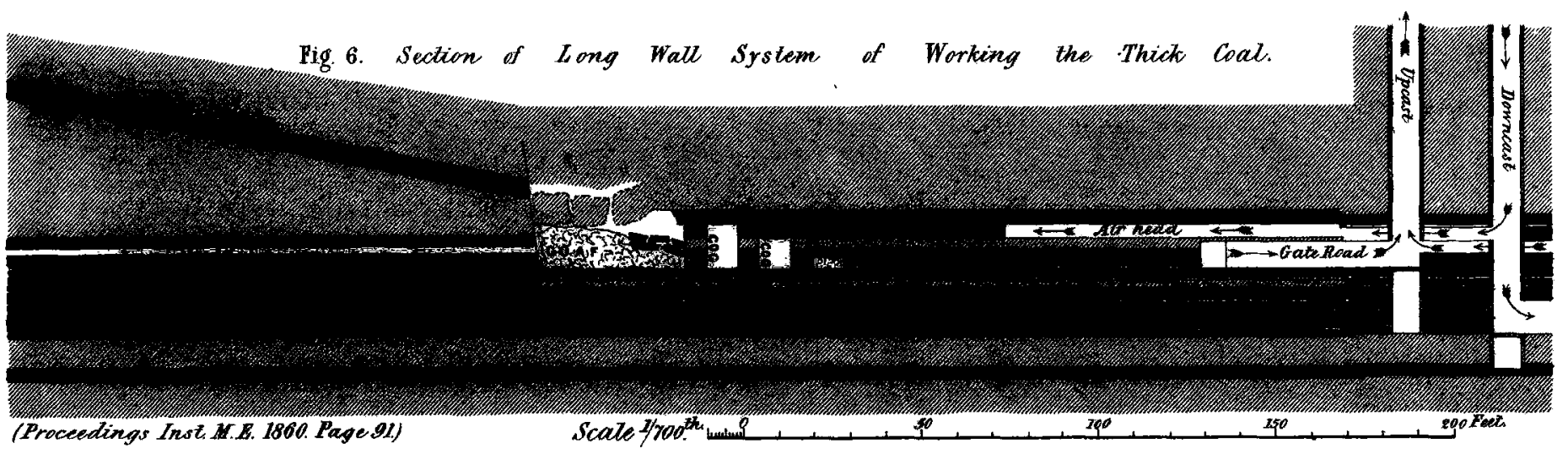

Downloaded from pme.sagepub.com at UNIV OF SOUTHERN CALIFORNIA on June 4, 2016 


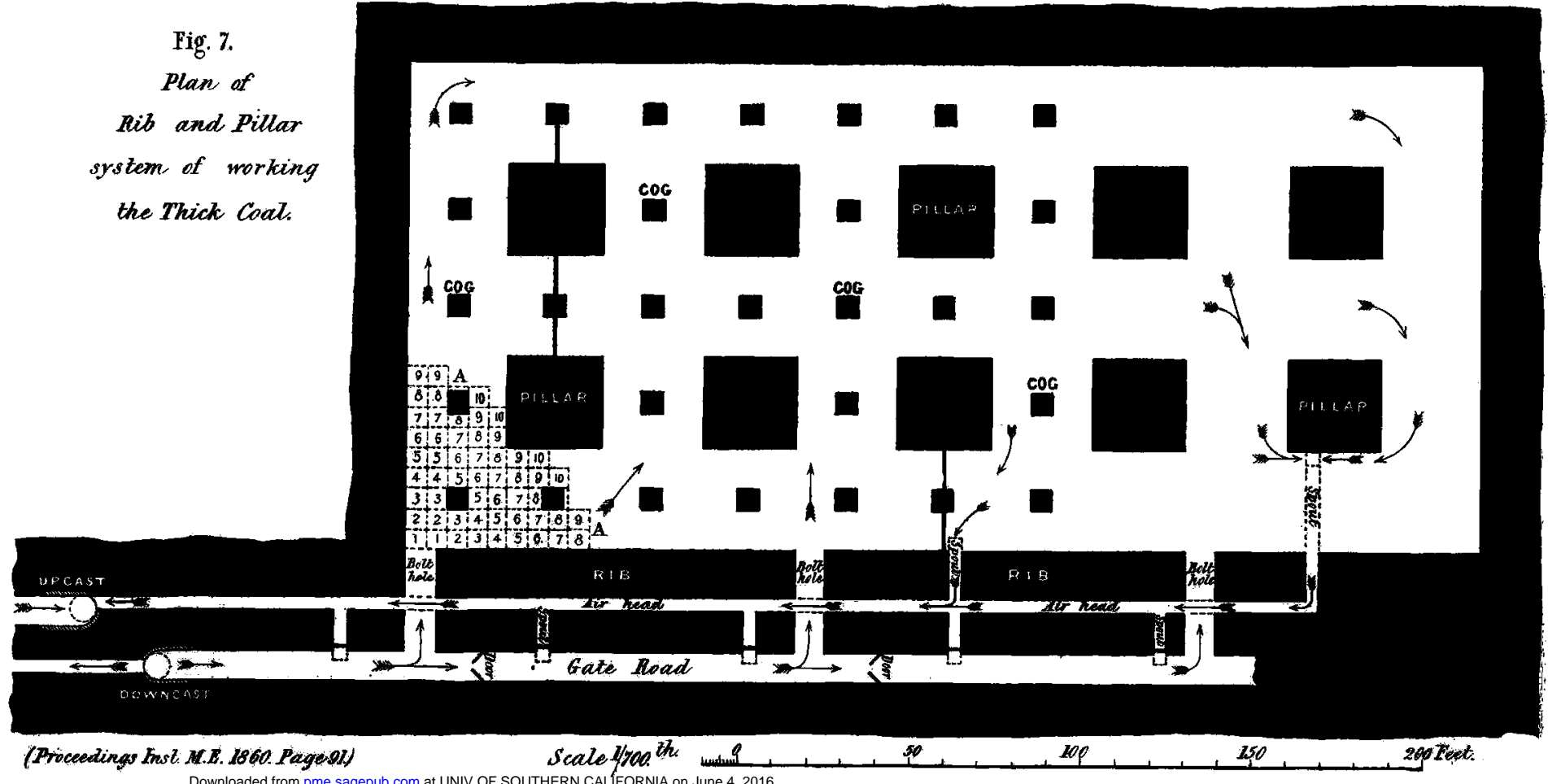


SOUTH STAFFORDSHIRE THICK COAL.

Plate2.

Fig.8. Plan of Long Wall system of working the Thick Loal.

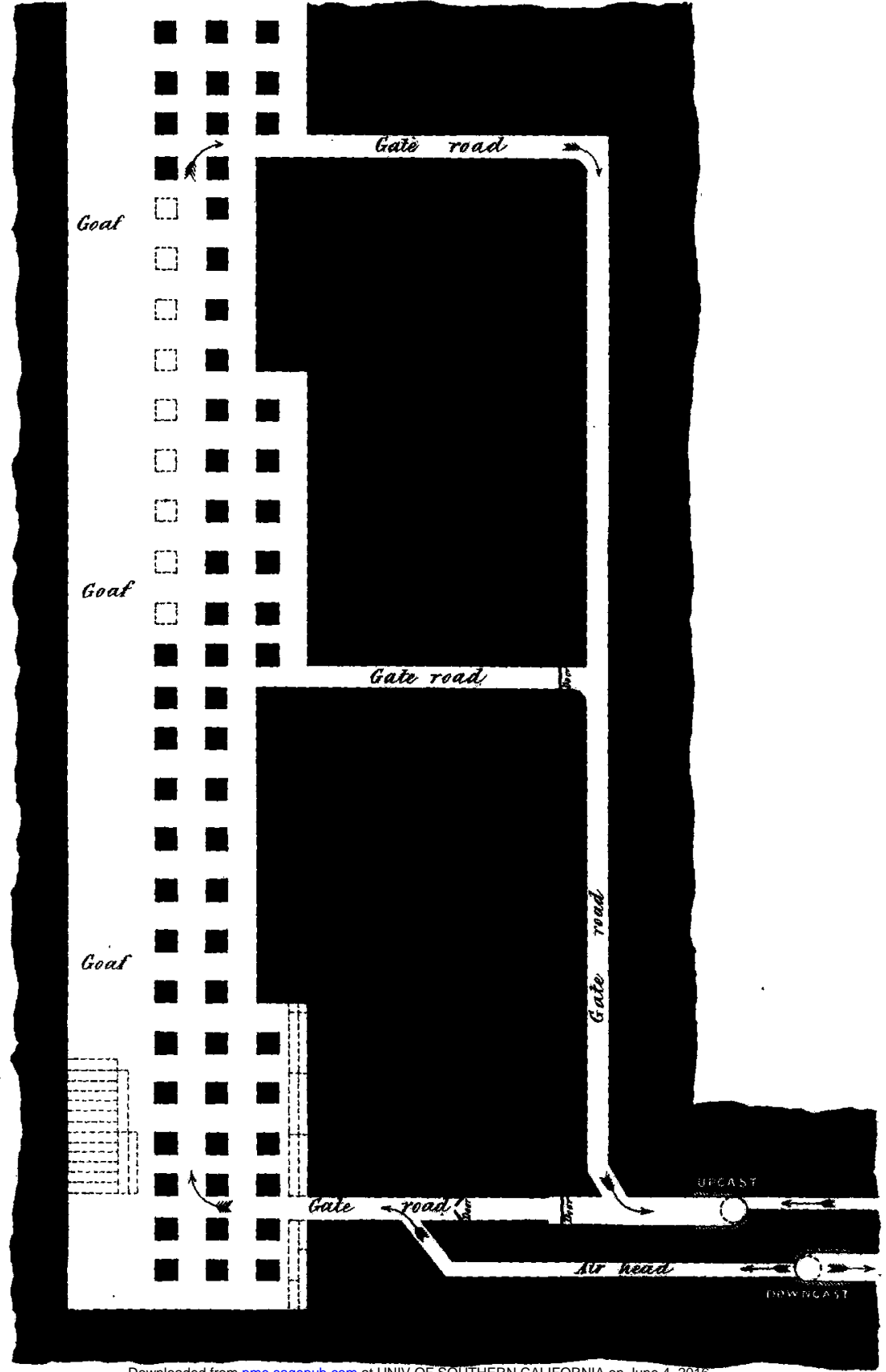

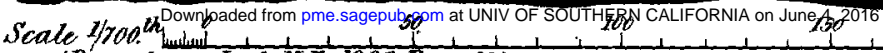
200 Peet: 
Fig.9. Section of Dislocated Position of Thick Coal in Corbyn's Hall Colliery.

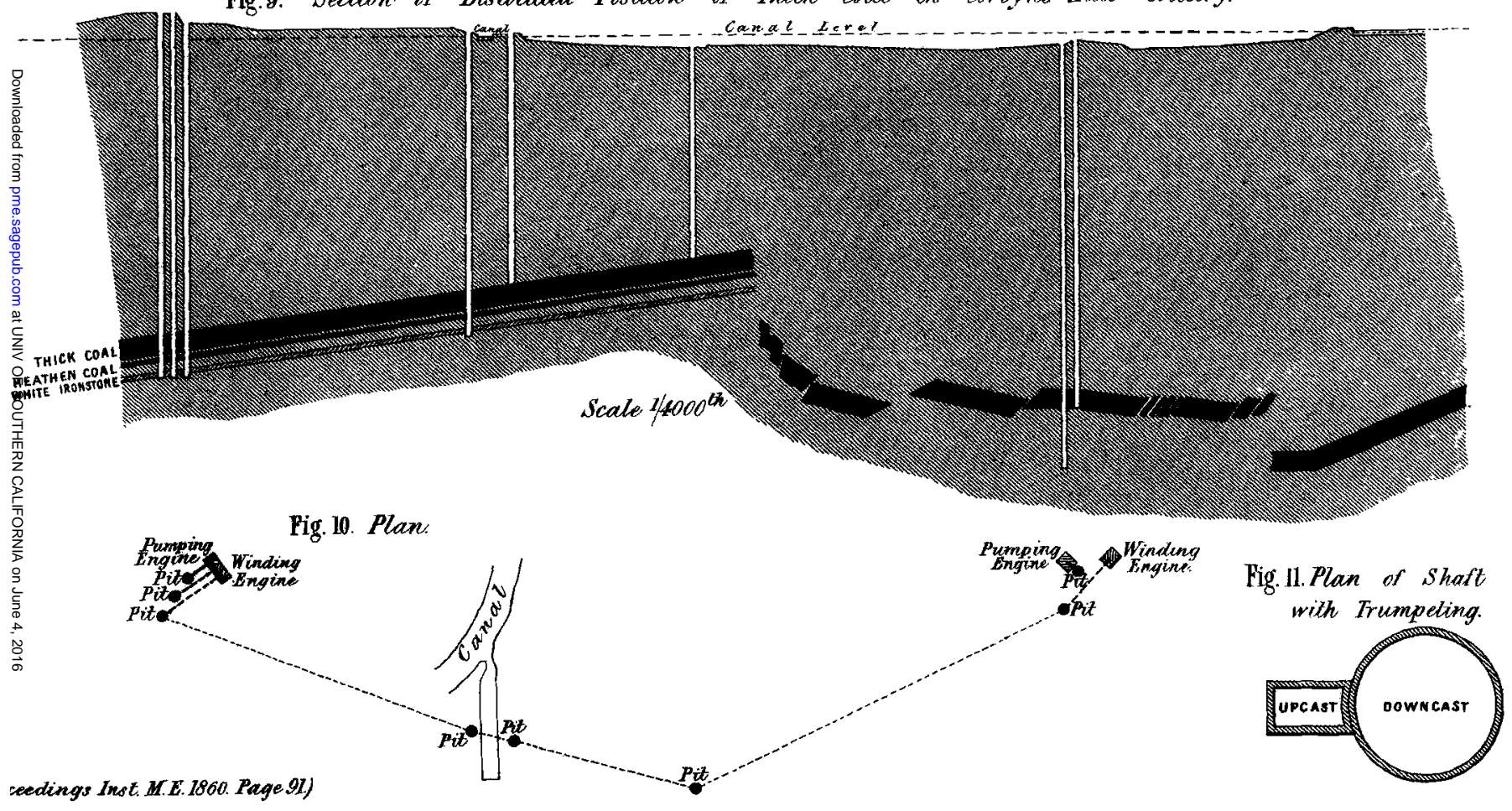




$$
\text { Sections of Thick Coal. }
$$

Fig. 12.

Corbrnis Hall Colliery Kingswinford.

Western districh.

(Table 1.)

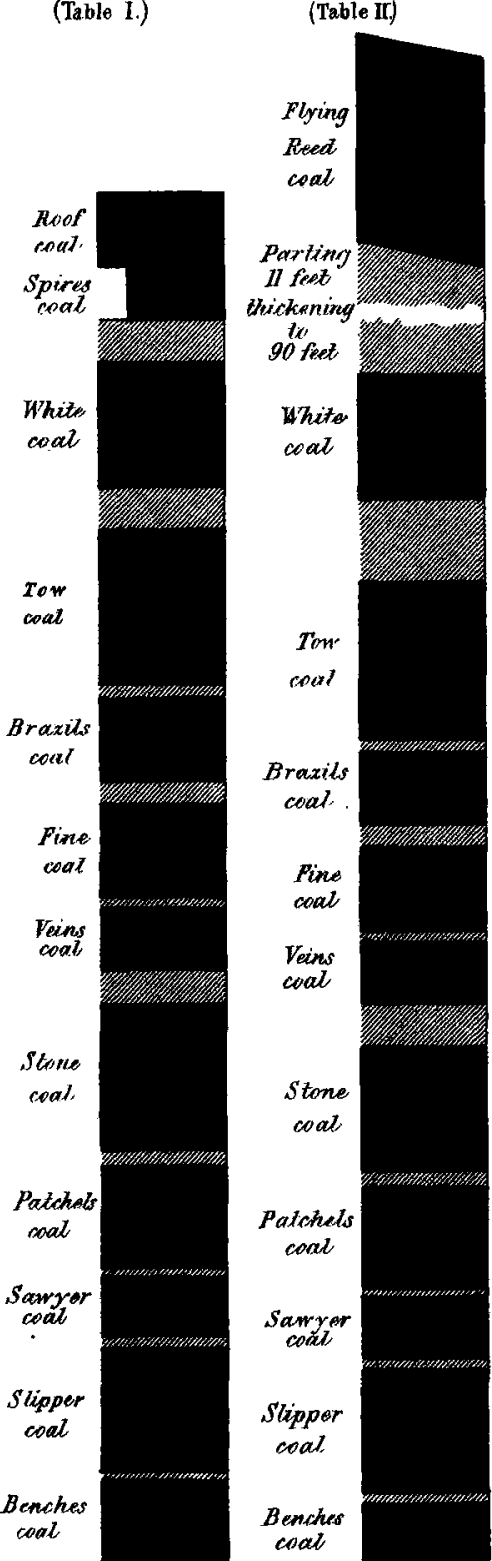

Fig. 14.

Hawn Colliern. Hales orren:

Western districl.

(Table IIL)

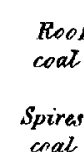

cral

White

coal

Tor

cout

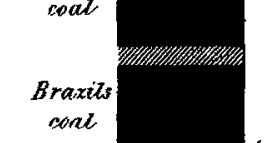

sant

Fin

Vein

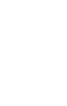

stono

Parchets

Patchets

coat.

Sawye
coat

slipper

coat

Bryches
Fig. 15.

Tividale Colliery, nowley.

Fiastern ilistrick

(Table IV.) 